\title{
The Polish Constitutional Court AND POLITICAL "REFOLUTION" AFTER 1989: BETWEEN THE CONTINUITY AND DISCONTINUITY OF THE CONSTITUTIONAL NARRATIVE*
}

\author{
ALEKSANDRA KUSTRA-ROGATKA**
}

"(...) History is like the ocean. Years of quiet, when gentle wind blows and waves splash against the shores, alternate with stormy times, when waves rise like mountains and hit against the shore as if they would swallow the land. In history, as well, there are periods of quiet, continuous development, but there are also periods of fierce and aggressive change, when the dormant forces of history erupt onto the surface."

A. Visegrády ${ }^{1}$

\section{INTRODUCTION}

Timothy Garton Ash coined the expression "refolution". It fits in Poland's case, as it semantically blurs the border-line between historical periods of stormy times (revolution) and times of quiet, continuous development (reform). ${ }^{2}$ According to Ash this term refers to a process of political, economic and social change that combines both elements of reform or structural modification with aspects of revolution. In essence, this means that instead of totally destroying the old system, the new democratic political systems are based on old regimes - both in terms of structures and personnel. Major purges of people at the top occur and important modifications to existing institutions take place, but in the main, the new

DOI: $10.1515 /$ wrlae-2018-0005

* The present paper represents exclusively the personal point of view of the author, and this should not be attributed to the Constitutional Tribunal of Poland or any other institution.

** PhD, Dr. habil., Head of Department of Theory of Law and State, Nicolaus Copernicus University, Toruń. Email: a kustra@umk.pl.

1 'Transition to Democracy in Central and Eastern Europe: Experiences of a model country - Hungary' 1.2 William and Mary Bill of Rights Journal 245.

${ }^{2}$ See TG Ash, The Magic Lantern: The Revolution of '89 Witnessed in Warsaw, Budapest, Berlin, and Prague (Vintage Books 1993). 
political system relies heavily on its predecessor. ${ }^{3}$ Therefore, if the Polish "refolution" after 1989 can be considered a revolution at all, it was a "constitutional" or "negotiated" one. ${ }^{4}$

Despite the evolutionary character of the Polish political transition, the constitutional narrative was considered as a way of marking a sharp break between the (bad) past and the (better) present. ${ }^{5}$ It may be described as a narrative of discontinuity. ${ }^{6}$ Such a narrative characterised both the constitution-writing process and the judicial review of the law that had been in place under the former regime.

In the sphere of constitution-writing the narrative of discontinuity was stressed by Lech Garlicki, a distinguished Polish legal scholar and judge of the Polish Constitutional Court (hereinafter: the CC) and European Court of Human Rights, when he stated that:

"The fall of communism resulted, among other things, in an end of "socialist constitutions" - they had been replaced with the new ones. The ideal picture of new constitutions was rather obvious: they should follow (imitate) democratic constitutions of the Western world. There were several hopes as to the functions to be fulfilled by the new constitutional elements: to demonstrate clear rejection of the communist past, to create legal foundations of the new democratic

\footnotetext{
${ }^{3}$ D Herspring, “' 'Refolution' in eastern Europe: The Polish, Czech, Slovak and Hungarian militaries" (1994) 3.4 European Security 664.

${ }^{4}$ See Visegrády (n 1) 246. A. Czarnota notes that "in a situation of 'controlled change', otherwise known as 'negotiated revolution', the rule of law too early declared can lead and usually does lead to a façade form of justice. It is less clear, however, that their thesis about the necessity for mass repression, surveillance and control does have a universal character in post-communist circumstances, or that it could ever be realized particularly under the circumstances of a negotiated revolution, or that it should be." A. Czarnota, "Transitional Justice, The Post-Communist Post-Police State and the Losers and Winners. An Overview of the Problem' (2009) 1 Silesian Journal of Legal Studies 13.

5 The pursuit of casting off the past was highlighted by the Prime Minister of Poland, Tadeusz Mazowiecki, in his first parliamentary speech in the Sejm, in 1989, when he used the term "thick line policy". He said, "We split away the history of our recent past with $a$ thick line. We will be responsible only for what we have done to help extract Poland from her current predicament, from now on." (Przeszłość odkreślamy gruba linia. Odpowiadać będziemy jedynie za to, co uczyniliśmy, by wydobyć Polskę z obecnego stanu załamania.) However, in more recent years, his intentions have been misunderstood - sometimes deliberately - by some people, and his gruba kreska is often understood as a policy of nonpunishment for crimes committed by the communist regime of pre-1989 Poland.

${ }^{6}$ See C Schmitt, Theory of Constitution-making Power (Duke University Press 2008) 144. İlker Gökhan Şen notes that Schmitt discerns two patterns of constitutional revolutions. Firstly "the constitutional annihilation" which is the simultaneous abolition of the existing constitution as the whole and the constituent power that supports it." Contrarily "constitutional elimination" is simple eradication of the extant constitution, but by retaining the concurrent constituent power. In the former case, the constituent agent obliterates "the very foundation of the prior constitution" with the aim of the conscious break with the past", through this process a new subject of the constituent power emerges along with the new established constitution. Yet in the case of the constitutional elimination and despite the entire abolition of the constitution, the existing constituent power remains intact. Thus, Schmitt discerns two types of legal and constitutional discontinuity, one that results in simultaneous "elimination of the identity of the political unity" and the other that does not. İlker Gökhan Şen, Sovereignty Referendums in International and Constitutional Law (Springer 2015) 130-131.
} 
order, to describe and confirm the new identity of the nation (country)." "

This observation on the early stage of the "Polish refolution" might be perceived through the Lacanian theory of three orders: the Imaginary, the Symbolic, and the Real. The Imaginary is associated (albeit not exclusively) with the restricted spheres of consciousness and self-awareness. It is the field of images and imagination, and deception. The Lacanian Symbolic initially is theorized on the basis of resources provided by structuralism. The Symbolic is a linguistic dimension, in which elements have no positive existence, but which are constituted by virtue of their mutual differences. This order also refers to the customs, institutions, laws, mores, norms, practices, rituals, rules, traditions, and so on of cultures and societies (with these things being entwined in various ways with language). The Real, for Lacan, is that which is outside language and that resists symbolization absolutely. When one looks at the Polish "refolution" through the prism of the Lacanian three orders theory, the constitution is the element of Imaginary order. In the Symbolic order there is above all the aspiration for Western democracy and the rule of law, our "ideal ego" - the idea of what we would like to be, whereas in the Realm there is continuity, lasting in the Old. Nevertheless, the Realm is not verbalized in the public discourse. It is negated, displaced. Such a perception of the Polish 'refolution' helps to understand the dual existence of constitutional continuity and discontinuity during the systemic transition of the state.

Adam Czarnota - a distinguished Polish legal scholar specialized in the sociology of law and transitional law - has called the legal continuity of the Lacanian Realm "the original sin of negotiated revolution" and pointed out that: "from the very beginning old and new law have coexisted. In many cases the old law was impossible to replace by new legislation or the activism of judges, especially constitutional judges. This structural coexistence has created numerous problems for the implementation of the change." $"$

The Lacanian Imaginary order of casting off the old is clearly visible in the binding Polish Constitution of 1997. The attitude toward the past is articulated as early as in the preamble, in which the citizens of Poland establish a Republic:

"Recalling the best traditions of the First and the Second Republic ${ }^{9}$, obliged to bequeath to future generations all that is valuable from our

\footnotetext{
7 L Garlicki, "The Necessity and Functions of the Constitution" paper given at the Symposium on the "European Constitutional Area" held at the Swiss Institute for the Comparative Law, Lusanne, Switzerland, 9-12 April 1995.

${ }^{8}$ A Czarnota, 'Foreword' (2001) 29 East Central Europe (part 1) V.

${ }^{9}$ The First Polish Republic was the Polish-Lithuanian Commonwealth, (also known as the Commonwealth of Both Nations (Polish: Rzeczpospolita Obojga Narodów; the Republic of Nobles and Aristocrats, Rzeczpospolita szlachecka or as the First Commonwealth I Rzeczpospolita). It was a dualistic state, a bi-confederation, of Poland and Lithuania ruled by a common monarch, who was both the king of Poland and the grand duke of Lithuania. It was one of the largest and one of the most populous countries of 16th- and 17th-century
} 
over one thousand years of heritage ... Mindful of the bitter experiences of the times when fundamental freedoms and human rights were violated in our Homeland, $(\ldots)^{10}$."

Many provisions of the binding Constitution were also written explicitly to rectify the wrongs of the communist regime. ${ }^{11}$ Since the constitution-writing process needs time, the constitutional narrative of discontinuity usually begins with the reinterpretation of the old constitution, until the new one is finally enacted and enters into force ${ }^{12}$. Such reinterpretation - coherent with new democratic axiology - belongs to the judiciary. In countries where the Kelsenian concentrated model of constitutional review exists, as is the case in Poland, this is mainly the constitutional court's task. ${ }^{13}$

It seems quite clear, that regardless of the stage of the political transition, both the drafters of the constitution and the constitutional judiciary tend to distance themselves from the past. However, the "the original sin of negotiated revolution" made it impossible. The paradigm of constitutional discontinuity represents the Lacanian Imaginary, whereas in the Realm there is continuity, lasting in the Old. This article aims to analyse the tug-of-war between both orders observed in the case-law of the CC regarding the communist regime.

Europe, with some 450,000 square miles $\left(1,200,000 \mathrm{~km}^{2}\right)$ and a multi-ethnic population of 11 million at its peak in the early 17 th century. The Commonwealth was reduced in the First Partition of Poland in 1772 and disappeared as an independent state after the Third Partition of Poland in 1795. The Second Polish Republic, also known as the Second Commonwealth of Poland or the interwar Poland, refers to the country of Poland between the First and Second World Wars (1918-1939). Officially known as the Republic of Poland or the Commonwealth of Poland (Polish: Rzeczpospolita Polska), the Polish state was recreated in 1918, in the aftermath of World War I. The preamble excludes the period of Polish People's Republic.

${ }^{10}$ The phrase "Mindful of the bitter experiences of the times when fundamental freedoms and human rights were violated in our Homeland" refers to the period of the Polish People's Republic (1945-1989), although the name was not officially adopted, however, until the proclamation of the Constitution of the Polish People's Republic in 1952.

${ }^{11}$ Article 20 states the principle of the social market economy as the basis for the economic system casting off the old centrally planned economy. Article 23 established the family farm as the basis of the agricultural economy, in response to communist-era collective farming. Articles 39 and 40 forbid torture and corporal punishment, while Articles 50 and 59 acknowledge the inviolability of the home, the rights to form trade unions, and to strike.

${ }^{12}$ Jiři Prribán̆ notes that "As regards the problem of legal continuity and discontinuity, postcommunist legal systems were a typical example of the politics of legal continuity and the fast enactment of new laws which would gradually replace the communist legal system. This process was extremely dynamic and reflected the revolutionary changes in the postcommunist societies. ”Jiří Přibán̆, Legal Symbolism: On Law, Time and European Identity (Ashgate 2007) 142-143.

${ }^{13}$ More on the subject see: W Sadurski, The Study of Constitutional Courts in Postcommunist States of Central and Eastern Europe (Dortrecht, Springer 2005), R Uitz, Constitutions, Courts and History. Historical Narratives in Constitutional Adjudication (Central European University Press 2005), A Czarnota, 'Guardians of the Constitution or legislative Bodies?' (2001) 28 East Central Europe (part 1) 147-152. 


\section{IMAGINARY AND SYMBOLIC VERSUS REALM. THE NARRATIVE OF DISCONTINUITY VERSUS THE CONTINUITY OF THE "CONSTITUTIONAL ENVIRONMENT".}

As Mark Brzeziński - an American lawyer and diplomat - points out, at the very beginning of its existence in the Polish constitutional system the $\mathrm{CC}$ was an unwanted child of the communist regime and existed in the political structure which still aspired to the principles of legislative supremacy and the unity of state power. ${ }^{14}$

In the autumn of 1981, legal experts began to work on the establishment of the CC and the Tribunal of State, and the constitutional amendment of 26 March 1982 provided for the introduction of these two institutions into the Polish legal system. The Tribunal of State Act was adopted on the same day, thus enabling the functioning of this institution a few months later; the Constitutional Court Act, however, was not adopted until 29 April 1985 (hereinafter: the CCA 1985) ${ }^{15}$, after three years of strenuous conflict concerning its form. Influential groups opposed the idea of establishing the constitutional court as such, rightly considering this institution independent and thus difficult to be politically subordinated. ${ }^{16}$

According to Hanna Dębska and Tomasz Warczok - Polish scholars specialized in the sociology of law - the fact that the CC commenced its activities in 1986, i.e. under the communist regime, facilitates presenting this institution as a specific 'carrier' (interpreted as Weber's Trager of democracy). Therefore, it not only constituted a link between two opposing systems, but was also an active entity engaged in establishing a new order in a state under the rule of law. ${ }^{17}$

This institutional position can be paralleled with the physical environment of the CC. It was hastily assembled in a room in the basement of the Polish parliament. There were no judicial chambers. There was no supporting staff. ${ }^{18}$ This situation continued until 1991, when the CC was given its own wing in the parliament building. ${ }^{19}$ During its three first years (up to the end of 1988) the CC did not focus on the review of parliamentary statutes. ${ }^{20}$ Only three of the thirty-three cases the CC decided between 1986

\footnotetext{
${ }^{14} \mathrm{M}$ Brzezinski, in 'Constitutional 'Refolution' in the Ex-Communist World: The Rule of Law (1997) 12 American University International Law Review 90-91, for further on this issue see: P Sarnecki, 'Ustrój polityczny Polski po wejściu w życie ustawy konstytucyjnej z 7 kwietnia 1989 r.’, (2009) 3(92) Przegląd Sejmowy 17.

15 Dz.U. 1985, No. 22, item 98.

${ }^{16}$ Further on the issue of the genealogy of the Polish CC: see: A Sulikowski, 'Government of Judges and Neoliberal Ideology: The Polish Case' in Cosmin Sebastian Cercel, Rafał Mańko, Adam Sulikowski (eds) Law and Critique in Central Europe: Questioning Past, Resisting Present (Countepress 2016)

${ }^{17}$ H Dębska, T Warczok, 'Sacred Law and Profane Politics. The Symbolic Construction of Constitutional Tribunal' (2014) 4(188) Polish Sociological Review 469.

${ }^{18}$ Brzezinski (14) 90-91.

19 The present seat of the CC is located in Warsaw, at al. Szucha 12Aa. The CC moved from its provisional premises at the Sejm to its new building in January 1995. The official inauguration of the CC's new seat was held on February 1st of that year.

${ }^{20}$ However, as M. Brzezinski notes "From its very first case in 1986, the Tribunal began to strike down executive acts which lacked sufficient statutory basis. It adopted a narrow
} 
and 1989 concerned acts of parliament. ${ }^{21}$ And of those three only one was found to be unconstitutional. ${ }^{22}$

After 1989, the CC's practice of judicial review blossomed and it turned out to be a key player in the constitutional transformation. The CC became much more aggressive in reviewing acts of parliament and abandoned its reluctance to address controversial issues. Practically every question regarding the separation of powers, every socio-economic issue, and issues of lustration and decommunization have come before the CC. ${ }^{23}$

M. Brzezinski notes that the CC's self-confidence was also enhanced by the change in its composition. Half of the justices completed their terms of office and were replaced by six new ones in November 1989. "Solidarity"24 took advantage of this opportunity and packed the court with its own candidates. $^{25}$

construction of an executive agency's right to issue regulations and held that only explicit statutory delegations authorize the executive branch to issue regulations. For example, a 1986 case involved a statute passed by Parliament to combat alcoholism that limited consumer access to alcohol. The statute authorized the government to decrease the number of state-owned liquor shops in Poland. And implementing the statute, the Council of Ministers issued regulations that reduced by ten percent the number of liquor shops in the country. But in an action not provided for by the statute, the Council of Ministers, in a subdelegation of authority, empowered the Minister of Trade to further reduce the number of liquor shops in regions with a high incidence of alcoholism. And that sub-delegation of authority was struck down by the Tribunal. This decision was one of almost thirty decisions between 1986 and 1989 in which the Tribunal voided an executive regulation for exceeding the scope of a statute" (Brzeziński (n 14) 91).

${ }^{21}$ Cases K 1/86, K 1/87 and K 1/88.

${ }^{22}$ Brzezinski (n 14) 90-91. The only case in which the CC concluded the unconstitutionality of the statute was case $\mathrm{K} \mathrm{1/88.} \mathrm{It} \mathrm{regarded} \mathrm{social} \mathrm{rights} \mathrm{of} \mathrm{disabled} \mathrm{people.}$

${ }^{23}$ R Cholewiński notes that "Between 1989 and 1994, the CC increased its activity by interpreting statutes more aggressively, addressing controversial constitutional issues such as religious instruction in schools and abortion, and resorting to international law to assist it in the interpretation of domestic law. Despite this more prominent and active role, some of the CCs controversial decisions were inevitably plagued by politics. Parliamentary resolutions to overrule or to uphold $\mathrm{CC}$ rulings on the conformity of statutes with the Constitution were frequently based on non-constitutional considerations, a position exacerbated by Poland's difficult economic situation." R Cholewiński, "The protection of Human Rights in the new Polish constitution' (1998) 22.2 Fordham International Law Journal 283.

24 Polish: Solidarność; full name: Niezależny Samorządny Związek Zawodowy "Solidarność" (Independent Self-governing Trade Union "Solidarity") was a Polish trade union that was founded on 17 September 1980 at the Gdańsk Shipyard under the leadership of Lech Wałęsa. It was the first trade union in a Warsaw Pact country that was not controlled by a communist party. Its membership reached 9.5 million members before its September 1981 Congress (when it reached 10 million), which constituted one third of the total working-age population of Poland. In the 1980s, Solidarity was a broad antibureaucratic social movement, using the methods of civil resistance to advance the causes of workers' rights and social change.

${ }^{25}$ Brzezinski (n 14) 92-93. It should be noted that there were twelve judges chosen to the first bench of the CC. Half of them were appointed for a four-year term, the others for an eight-year term. The term of the judges appointed for a four-year term ended after the Polish Round Table Agreement and after the parliamentary election of 1989, won by Solidarity. Thanks to this fact six new judges of the CC, who were appointed in 1989, were chosen by political groups which had public support. As a result, the CC earned its legitimacy and without any major difficulties maintained its institutional continuity in spite of the changes of 1989. It was rather an exceptional situation in regard to the Polish judiciary. For instance, the bench of the Supreme Court was changed root and branch, as in the second half of the 1980s the Supreme Court had passed its judgments in accordance 
After 1989 the narrative of discontinuity was developed. This is borne out by the statistics. From 1990 until the first half of 1994, of fifty-two statutes the $\mathrm{CC}$ reviewed, forty were found to be unconstitutional, which is a large percentage when compared to any other European constitutional court, or even to the American Supreme Court's constitutional review of statutes. This proves that the political 'refolution"' started in 1989 caused a dramatic change in the CC's jurisprudence. ${ }^{26}$

The most remarkable development in the CC's practice after 1989 resembles what the German Bundesverfassungsgericht (constitutional court) has done since the 1970 s, i.e. to develop and protect substantive rights on the basis of general constitutional clauses. Similarly to the German case, the Polish constitution's Rechtsstaat clause ("democratic state ruled by law") was a particularly important tool for the $\mathrm{CC}$ in this area. ${ }^{27}$ This is no surprise, as Michel Rosenfeld rightly observes:

"The rule of law is the cornerstone of the contemporary constitutional practice as was underscored by its role in cementing the recent transitions from authoritarian or totalitarian regimes to constitutional democracy in Eastern Europe and elsewhere."28

However, it is a paradox that this catalyst of the narrative of discontinuity was introduced into the constitutional system in December 1989 as the amendment to Article 1 of the Constitution of 1952..29 It was a kind of "normative plug-in" element that enabled the reinterpretation of old constitutional provisions that remained in force. ${ }^{30}$ The constitutional

with the spirit of the communist state. (See M Zubik, 'Polish Constitutionalism and the Constitutional Judiciary in Poland V.6 Hungarian Review 3 (http://www.hungarianreview.com/article/Polish\%20Constitutionalism\%20and\%20the\%20 Constitutional\%20Judiciary\%20in\%20Poland). Therefore W Sadurski states, in regard to the old habits and ideologies of judiciary in postcommunist countries, that "perhaps the clearest case of a "purified" supreme court is provided by Poland, where all of the judges of the top judicial body were appointed anew after the transition of 1989; thus, their "moral mandate" to interpret the Constitution in accordance with a democratic system of values has been as good as that of the Constitutional Tribunal."

${ }^{26}$ Brzeziński (n 14) 93.

${ }^{27}$ Brzeziński (n 14) 91-92. Further on the issue of the judicial activism of Polish CC in the early 90's of the XX century see: B Banaszak, 'Aktywizm orzeczniczy polskiego Trybunału Konstytucyjnego' in B. Banaszak, M Bernadczyk (eds) Aktywizm sędziowski we wspótczesnym państwie demokratycznym (Warszawa 2012) 222-241.

${ }^{28}$ M Rosenfeld, 'The Rule of Law and the legitimacy of Constitutional Democracy', 74 Southern California Law Review 1307.

29 The Amendment from December 1989 also changed the name of the Polish country (from the Polish People's Republic to the Republic of Poland) and removed references to Poland being a socialist state.

${ }^{30}$ At the starting point of a transition, a constitutional court usually operates in the old "constitutional environment", at least in the sphere of legal texts. In Poland, the (reformed) 1952 Constitution $^{30}$ was fully repealed and completely replaced only in 1997, when the current 1997 Constitution came into force (17 October 1997). The so called Small Constitution, enacted in 1992, was the first transitional legal act of highest rank, yet it regulated only relations between legislative and executive branches and local selfgovernment. The judiciary branch, so therefore fundamental rights and freedoms, was still regulated by the Constitution of 1952 ? 
principle of the democratic state ruled by law served as the legal basis for the most active period in the judicial activity of the $\mathrm{CC}$, where the general and open-ended structure of this constitutional provision was used to develop diverse political principles and substantive rights such as the protection of vested rights, the principle of correct legislation, the right to fair trial. ${ }^{31}$

\section{THE NARRATIVE OF DISCONTINUITY VERSUS THE CONTINUITY OF THE ENVIRONMENT OF PROCEDURES AND COMPETENCE OF THE CC}

Another aspect of the continuity of the CC's legal environment is the consequence of the fact that until 1997 the CC operated on the basis of the old legal regulation regarding the scope of its competences and procedure, i.e. the Constitution of 1952 and the CCA 1985. The latter act was a result of a compromise reached with much difficulty. It contained a number of limitations upon the CC's position and competences. One of them followed from the constitutional regulation, since the constitutional amendment of 1982 established the CC on one hand, but on the other it acknowledged the final character of only some of the CC's decisions. Decisions on the unconstitutionality of statutes were subject to review by the Sejm (the single parliamentary chamber), which could overrule the CCs decisions by having a two-thirds majority. ${ }^{32}$ Such a solution was an attempt at a compromise between the establishing of the constitutional review and maintaining the principle of the unity of state authority ${ }^{33}$. The actual effect was that the decisions on the constitutionality of statutes were subjected to the will of the parliament, in other words - under then-contemporary circumstances - to the Communist Party. The constitutional amendments of 1989 did not abrogate this rule and it was still a competence of the Sejm - which became one of the two parliamentary chambers (along with the Senate ${ }^{34}$ ) - to

\footnotetext{
${ }^{31}$ Among others cases K 14/96 (the right to a fair trail), K 11/93 (judicial independence), K 1/94 (non-retroactivity of law), U 6/92 (separation of powers), K 6/93 (protection of vested rights). See also: MF Brzezinski, L Garlicki, 'Judicial Review in Post-Communist Poland: The Emergence of a Rechtsstaat?' (1995) 16 Stanford Journal of International Law 13-60; B Banaszak, M Bernadczyk (n 27) 222-241; L Morawski, 'Spór o pojęcie państwa prawnego' (1995) 8 Państwo i Prawo.

32 The same majority was required to amend the 1952 Constitution.

${ }^{33}$ The principle of the unity of state authority, which is antithesis of the tripartite division of powers, was introduced in 1952 Constitution. The 1952 Constitution recognized the legislature as the highest authority in the state apparatus. All other organs were subordinated to the Sejm and bound by its decisions. See: S Frankowski, PB Stephan III (eds), Legal Reform in Post-communist Europe. The View from Within 24.

${ }^{34}$ The Senate (Polish: Senat) is the upper chamber of the Polish parliament. The history of the Polish Senate is rich in tradition and stretches back over 500 years. It was one of the first constituent bodies of a bicameral parliament in Europe and existed without hiatus until the dismemberment of the Polish state in 1795. After a brief period of existence in the interwar period the Senate was again abolished (by many accounts illegally) by the authorities of the People's Republic of Poland, it was not re-established until the collapse of communism, after the agreement struck between the Communists and Solidarity in 1989. The final agreement was signed on April 5, 1989. As a result, real political power was vested in a newly created bicameral legislature and in a president who would be the chief executive. Solidarność became a legitimate and legal political party. One of the most
} 
overrule the CC's decisions concerning the constitutionality of statutes. In the 1990s, subsequent governments were unable to change this status quo.

The breakthrough came when the Constitution of 2 April 1997 entered into force on 17 October 1997 and the Constitutional Court Act of 1 August 1997 (hereinafter: the CCA 1997) ${ }^{35}$ - adjusted to the new constitutional regime - was adopted. With reference to the above, it must be stressed that until 1997 the parliament reflected the judicial narrative of discontinuity $^{36}$ (pursuant to Article 239 of the Constitution of 1997, and partially even until 1999). ${ }^{37}$

This happened, for instance, in the CC's judgment of 20 November 1996 in case K 27/95 concerning the constitutionality of the Workers' Allotments Gardens Act $1981^{38}$ (hereinafter the 1981 Act). In this ruling, the CC held in a full court sitting (12 judges) that several crucial provisions of the 1981 Act were contrary to the principle of the democratic state ruled by law (Article 1 of the Constitution of 1952, as amended) due to the fact that the Polish Association of Allotment Holders (in Polish: Polski Związek Działkowców hereinafter: PZD) had the status of a monopolist. In the CC's opinion, the PZD's unconstitutional privileges concerned several issues, most of all the position of the PZD with regard to other organizations for allotment holders, the situation of the owners of land where allotment garden sites were situated and also relations between the said PZD and allotment holders who were members thereof. Nevertheless, the Sejm decided to annul the CC's judgment.

It should be noted that findings of the CC overruled by the Sejm were sustained in the judgment of 11 July 2012 (K 8/10) regarding the constitutionality of the new statute that regulated the PZD (Act of

important decisions reached during the talks was to allow for partially free elections to be held in Poland. All seats to the newly created Senate of Poland were to be elected democratically, as were 161 seats (35 percent of the total) in the Sejm (so called Contract Sejm, Polish: Sejm kontraktowy). The remaining $65 \%$ of the seats were reserved for the Communist Party and its satellite parties. In addition, all 35 seats elected via the countrywide list were reserved for the Party's candidates provided they gained a certain quota of support. This was to ensure that the most notable leaders of the Communist Party were elected. The election of June 4, 1989 (and the second round of June 18) brought a landslide victory to Solidarnośc: $99 \%$ of all the seats in the Senate and all of the possible seats in the Sejm. Out of 100 seats in the Senate, 99 were won by Solidarity and 1 by an independent candidate.

${ }^{35}$ Dz. U. No 102, item. 643, as amended. It should be, however, noted that the new Act on the Constitutional Court was passed by the Sejm on 25th June 2015 (Official Journal of the Republic of Poland item 1064). The Constitutional Tribunal Act 2015 came into force on 30th August 2015.

${ }^{36}$ Pablo de Greiff, 'International Courts and Transitions to Democracy' (1998) 12.1 Public Affairs Quarterly 74-75.

${ }^{37}$ Pursuant to Article 239(1) of the Constitution: "Within 2 years of the day on which the Constitution comes into force a judgment of the $\mathrm{CC}$ of the non-conformity to the Constitution of statutes adopted before its coming into force shall not be final and shall be required to be considered by the Sejm which may reject the judgment of the CC by a twothird majority vote in the presence of at least half of the statutory number of Deputies. The foregoing provision shall not concern judgments issued in response to questions of law submitted to the CC."

38 (Dz. U. z 1996 r. No 85, item 390, as amended). 
8 July 2005 on Family Allotment Gardens, hereinafter: the 2005 Act) ${ }^{39}$, which was mostly a "cut and paste" copy of the 1981 Act, as it did not change any of the monopolist privileges of the PZD.

The CC (in a full court sitting) maintained its findings and conclusions arising from the $\mathrm{K} 27 / 95$ judgment as well as from later judgments regarding both the 1981 Act (judgment of 20 February 2002 r., case K 39/00) and 2005 Act (judgment of 9 December 2008, case K 61/07). All of the aforementioned CC's judgments declared the unconstitutionality of the 1981 Act's provisions and the 2005 Act's provisions that had guaranteed a monopolist position to the PZD as regards access to land and the management of allotment garden sites (according to the 1981 Act: workers' allotment gardens; according to the 2005 Act: family allotment gardens).

In all of the said cases, the CC clearly emphasised the substantive aspect of the principle of a democratic state ruled by law, which required that the law reflect values corresponding to the values of a democratic state, including the freedom of association. Citizens who wish to associate to conduct their activity together should be guaranteed the freedom to choose the form of their legal organisation, depending on the goals they are trying to achieve.

The $\mathrm{CC}$ reiterated in case $\mathrm{K}$ 8/11its standpoint made in case $\mathrm{K}$ 27/95 and declared that the legal guarantee of exclusive access of the PZD to land assigned for allotment garden sites was contrary to the principle of a democratic state ruled by law, because it gave the PZD a monopoly on managing allotment garden sites guaranteed by statutory law. ${ }^{40}$

The CC's case-law over allotment gardens shows that the old environment of procedures and competence significantly relativised the effects of the CC's judicial decisions in early 90's of the XX century. Consequently, till the 1997 Constitution entered into force, the narrative of discontinuity had limited influence on the legal system.

However, even the post-1997 jurisprudence of the CC leads to the conclusion that interpenetration of constitutional continuity and discontinuity narrations is still observed.

\footnotetext{
39 (Dz. U. No 169, item 1419, as amended)

${ }^{40}$ The CC also conducted a comparative legal analysis of the institution of allotment garden sites in neighboring states (Slovakia, the Czech Republic, Germany and Austria). In each of those legal systems, the institution of allotment garden sites was legally protected in a way that guaranteed the balanced protection of both the interests of the owners of the land and the interests of allotment holders. The basis for holding an allotment garden was a lease agreement and a sub-lease agreement. This had also been the case in Poland until the year 1949.
} 


\section{DISCONTINUITY NARRATION IN CASES OF "LEGAL SURVIVALS". THE TEMPORALITY OF JUSTICE. ${ }^{41}$}

One of the aspects is case-law regarding "legal survivals" of the old regime that became a constitutional issue before the CC after 1997. The term "legal survivals" suggests that it refers to regulations (mostly statutory) that "survived" the transition period and preserved their binding force in the new political system. ${ }^{42}$ The main problem regarding these "legal survivals" results from the fact that they were based on different axiological premises ${ }^{43}$ and consequently often did not conform to the new constitutional system (the CC's allotment jurisdiction over gardens serves as a good example). When such legal regulations were challenged before the CC they were confronted with the binding constitutional standards and quite often it turned out that they did not meet them. Nevertheless, when "legal survivals" concerned fundamental rights such as ownership, the rule of law had to be confronted with the principle of non-retroactivity. Therefore, such CC's judgments are another piece of evidence for the relativity of the narrative of constitutional discontinuity. This relativity is mostly an offshoot of the temporality ${ }^{44}$ and historicity ${ }^{45}$ of justice, which will be illustrated by two CC judgments. The first regards regulated rents in private buildings; the second regards the inheritance of farms.

\section{Regulated rents in private buildings (judgment of 13 January 2000, Case $P$ 11/98)}

From the conclusion of the Second World War until 1987, a legal regime operated in numerous Polish cities whereby lease relations for living quarters in privately-owned buildings was created on the basis of allocations made by the administrative authorities. The legislator called this regime "public management of apartments" and, subsequently, the "special rental procedure". Administrative regulation was accompanied by the strict protection of the stability of lease relations, together with the operation of official - very low - rent levels. These factors, which signify a radical limitation on private owners' rights, combined with other weaknesses of the

\footnotetext{
41 Term used by Jiří Přibáň in Legal Symbolism: On Law, Time and European Identity (Ashgate 2007).

${ }^{42}$ See: R Mańko, 'Survival of the Socialist Legal Tradition? A Polish Perspective' (2013) 4.3 Comparative Law Review; R Mańko, 'Weeds in the Gardens of Justice? The Survival of Hyperpositivism in Polish Legal Culture as a Symptom/Sinthome' (2013) 7.2 Pólemos Journal of Law, Literature and Culture 207-233; R Mańko, 'Demons of the Past? Legal Survivals of the Socialist Legal Tradition in Contemporary Polish Private Law' in Cosmin Sebastian Cercel, Rafał Mańko, Adam Sulikowski (eds) Law and Critique in Central Europe: Questioning Past, Resisting Present (Countepress 2016) 77.

${ }^{43}$ Further on the issue see: K Pałecki, 'Zmiany w aksjologicznych podstawach prawa jako wskaźnik jego tranzycji' in K Pałecki (ed) Dynamika wartości w prawie (Kraków 1997); K Pałecki, 'O aksjologicznych zmianach w prawie' in L Leszczyński (ed), Zmiany społeczny a zmiana w prawie. Aksjologia, Konstytucja, Integracja Europejska (Lublin 1999).

44 Temporality can be defined as the linear progression of past, present, and future.

45 The Blackwell Dictionary of Western Philosophy defines historicity as "denoting the feature of our human situation by which we are located in specific concrete temporal and historical circumstances."
} 
socialist economic system, led to a significant devaluation of the old (prewar) housing resources, discouraged the construction of new housing for rent and eliminated the rental market for housing. The rents paid by tenants even failed to cover the building maintenance costs which the owners were obliged by statute to pay.

The legislator's first modest step towards liberalising the rental of privately-owned housing was to prospectively abolish the "special rental procedure", as of 1987. This created the possibility for a landlord to freely dispose of their apartment, as of the moment when it was vacated by the previously "allocated" tenant. Nevertheless, the principles of protecting the stability of existing tenancy relations (including protection for the family members of a deceased tenant) and, primarily, the principles of regulating rent levels, were not significantly amended. Furthermore, owners, being natural persons (as opposed to, for example, housing cooperatives), received no state subsidies and, in one sense, they therefore bore the cost of the realization of social policy concerning housing.

As a result of the political transformation, based on respecting private ownership and recognising market economy principles, restoring owners the possibility to freely determine rent levels became an outstanding issue in the 1990s.

Simultaneously, the legislator needed to take account of the interests of tenants who were often persons with a low income and were accustomed to paying low rents. The Lease of Living Quarters and Housing Allowances Act 1994 (hereinafter 1994 Act) ${ }^{46}$ attempted to resolve this dilemma. As the title of the Act indicates, it regulated the leasing of living quarters (within both public and private resources) and, furthermore, the principles for taking advantage of a publicly-funded pecuniary social benefit, known as a "housing allowance", payable to persons on low-incomes living in quarters they do not own (e.g. as a lessee or housing cooperative member).

The 1994 Act required lessees living in public housing resources (belonging to communes/municipalities or to the State Treasury) to pay socalled regulated rent, determined by the commune/municipal councils pursuant to criteria specified within the $\mathrm{Act}^{47}$ which states that the maximum level of regulated rent shall not exceed 3\% of the annual replacement value of the living quarters. Article 56(2) of the 1994 Act, a transitional provision which was directly challenged in the present case, extended the applicability of provisions concerning regulated rents to living quarters owned by natural persons, whenever such a tenancy was established on the basis of an administrative decision or, alternatively, was concluded prior to the entry into force of provisions creating the administrative procedure for establishing lease relations in a particular location (i.e. until 1987).

Regulated rents for such living quarters were intended to operate for a transitional period lasting 10 years, from the moment the discussed 1994 Act entered into force until 31 December 2004. This meant that private owners, to whom the provision was addressed, were not only prevented from increasing rents beyond the level of $3 \%$ of the annual replacement value of the living quarters during this period but, furthermore, were

46 (Dz. U. 1994, No 105, item 509 as amended)

${ }^{47}$ Articles 25 and 26 of the 1994 Act), Article 25(2) of 1994 Act. 
required to accept a lower rent whenever the appropriate commune council determined such a rent for a particular location. It should be added that, since the levels of housing allowance (mentioned above) paid by communes were correlated with rent levels, many communes pursued a policy of setting rent levels lower than the statutory maximum of $3 \%$ of the annual replacement value of the living quarters.

The 1994 Act provided for the transitional application of provisions concerning regulated rents determined by commune councils at a level not exceeding $3 \%$ of the replacement value of living quarters to the lease of living quarters owned by natural persons, until 31December 2004, whenever this tenancy was established on the basis, or prior to the entry into force, of the former provisions concerning the lease resulting from an administrative decision.

The question of the constitutionality of the regulated rents appeared before the $\mathrm{CC}$ in connection with the examination firstly by the Supreme Administrative Court (hereinafter; the SAC) and, subsequently, by the Supreme Court (hereinafter: the SC) of public legal litigation between, on the one hand, a group of private owners of tenement buildings in Gdynia, and, on the other the Gdynia City Council, which passed a Resolution setting regulated rents at a level lower than $3 \%$ of the reconstruction value of the apartments. The owners of the aforementioned buildings challenged this resolution before the SAC, insofar as the setting of rent rates at a level lower than the statutory ceiling also applied to privately-owned living quarters. In December 1997, the SAC ruled that the Council's resolution was illegal insofar as it was challenged.

The SAC interpreted Article 56(2) of the 1994 Act in such a way that reference, in this section, to provisions concerning regulated rents was deemed to refer to the maximum rent level permitted by statute (i.e. $3 \%$ of the replacement value) and not to any lower level determined by the commune council for a particular location as regards living quarters belonging to that commune's resources.

At that time, a two-instance system of administrative judicial proceedings did not yet exist. ${ }^{48}$ The aforementioned administrative court judgment was, therefore, final and could only be reviewed by the SC under a special procedure known as "extraordinary revision" (rewizja nadzwyczajna). ${ }^{49}$ In the analysed case, such an extraordinary revision was brought before the Supreme Court by the President of the SAC, who alleged that the latter court had adopted a flagrantly erroneous interpretation of Article 56(2) of the 1994 Act in the context of other provisions, including Articles 25 and 26 of the same Act.

\footnotetext{
48 The two instances administrative judiciary was introduced in Poland by the 1997 Constitution.

49 More about this procedure see: Introduction to Polish Law, (eds) S Frankowski, A Bodnar (Hague, Kraków 2005) 118-119; R Mańko, 'Is the Socialist Legal Tradition “'Dead and Buried?" The Continuity of the Certain Elements of Socialist Legal Culture in Polish Civil Procedure' in Thomas Wilhelmsson, Elina Paunio \& Annika Pohjolainen (eds), Private Law and the Many Cultures of Europe (Alphen aan den Rijn: Kluwer Law International 2007) 94-99.
} 
In considering the extraordinary revision, the SC harboured doubts as to the conformity of the aforementioned statutory provision with the constitution and the (European) Convention for the Protection of Human Rights and Fundamental Freedoms (hereinafter: the ECHR) ${ }^{50}$, since this provision extended, for a transitional period, the application of regulated rents to privately-owned living quarters. Therefore, the SC decided to refer a question of law regarding this matter to the $\mathrm{CC}$.

The preliminary reference submitted by the SC was based upon the assumption that, as had been argued in the application for extraordinary revision, the correct interpretation of Article 56(2) of the 1994 Act differs from that adopted by the SAC. The SC considered that this provision requires regulated rents to be paid at levels determined by commune councils, not only by lessees of publicly-owned living quarters but also by lessees of privately-owned living quarters, as referred to in Article 56(1).

The SC drew attention to the fact that the 1994 Act imposes upon communes a ceiling on regulated rents ( $3 \%$ of the replacement value) but does not, however, impose any minimum limit. Communes may take advantage of the absence of such a lower limit and enjoy full discretion in setting rent levels, regardless of the actual maintenance costs for the living quarters. Private owners of living quarters, to whom Article 56 of the 1994 Act applies, are not only deprived of the possibility to influence who occupies their quarters but are also forced to apply rent levels which communes usually deliberately set lower than actual maintenance costs. The fulfilment of the legal obligation to maintain housing resources in an appropriate condition requires owners to seek finances from other sources (their own income or loans). In the light of provisions concerning income taxes, the resulting losses incurred by private owners of leased living quarters may not be deducted from the income they earned from other sources.

Such an understanding of Article 56(2) of the 1994 Act became the catalyst for the question of law referred by the SC which, in particular, expressed its doubts as to whether protection of lessees may be achieved at the exclusive expense and risk of a single social group - the owners of buildings and living quarters.

In the judgment of 13 January 2000, case P 11/98, the CC decided that the challenged provisions violated the constitutional right to ownership read in conjunction with the principle of a democratic state ruled by law and the principle of proportionality. ${ }^{51}$

The reasoning of the $\mathrm{CC}$ in the case was based on the premise that that the unconstitutionality of the reviewed provision did not arise by virtue of the application, for a transitional period, of regulated rents to arrangements where the owner (lessor) is a natural person but, rather, by virtue of the fact that a commune council's resolution may set such rent at a level lower than $3 \%$ of the annual replacement value of the living quarters. Nevertheless, the $\mathrm{CC}$ also highlighted the need to protect lessees' confidence in the fact that

\footnotetext{
50 Poland became party to the ECHR on 19 January 1993. Subsequently, it acceded to several Protocols to the ECHR.

${ }^{51}$ Simultaneously, the $\mathrm{CC}$ held that the reviewed regulation did not violate the principle of equality.
} 
regulated rents would not exceed this limit until the end of 2004. ${ }^{52}$ Therefore, the $\mathrm{CC}$ decided to defer the entry into force of its judgment by 8 months. ${ }^{53}$

Temporal effects of the CC's judgment reveal the relativeness of the thesis on constitutional discontinuity. Given this CC's decision, the SC admitted that the SAC judgment (challenged in the extraordinary appeal) infringed the still-operative (because of the aforementioned CC's decision on the temporal effects of its judgments) 1994 Act and, accordingly, modified this judgment, dismissing the complaint of a group of private owners against the Gdynia City Council. ${ }^{54}$

This fact shows that even the negative evaluation of the "legal survival's" constitutionality does not excuse the $\mathrm{CC}$ from taking into account the citizens' confidence in binding law (in the analysed case the lessees' confidence in the fact that regulated rents would not exceed this limit until the end of 2004).

\footnotetext{
52 Judge Biruta Lewaszkiewicz-Petrykowska, who was the first Judge-Rapporteur in this case (the second Judge-Rapporteur was judge Lech Garlicki), submitted a dissenting opinion. Incidentally, subsequent statutes concerning the level of rents for living quarters, issued in 2001 and 2004, did not entirely respect the criteria of constitutionality laid down in the judgment summarised herein, and were also challenged before the CC. (The CC judgments in cases K 48/01, dated $2^{\text {nd }}$ October 2002, and K 4/05, dated 19th April 2005).

${ }^{53}$ Under the Polish Constitution (Article 190 (3), judgments of the CC take effect from the day of their publication. However, the CC may specify another date for the end of the binding force of a normative act examined by it. Such time period may not exceed 18 months in relation to a statute or 12 months in relation to any other normative act. In practice, it is not clear when the CC should exercise this power and what it should take into consideration granting the time period of postponement. The solution provided in Article 190(3) was intended as a stimulus to a particular legislative response. Postponing the date for the end of the binding force of a normative act, the $\mathrm{CC}$ leaves the legislator time to make necessary adjustments to an unconstitutional act in order to ensure its conformity with the Constitution. Unfortunately, as it often turns out, the CC's judgments finding an act to be unconstitutional do not motivate the legislator to action. Although the time limits for the completion of legislative work are usually set relatively long, almost $40 \%$ of cases in which the so-called legal force postponement clause was applied, the CC's judgments are executed with a substantial delay (which may last for months). Therefore, the aim of this legal measure introduced into the Polish legal order, i.e. to smoothly eliminate defective normative acts from the legal system and to prevent loopholes in the law, has not been always accomplished. The CC's decisions to postpone the date for the end of the binding force of the unconstitutional provisions also causes major problems relating to the preliminary questions of courts to the $\mathrm{CC}$, as confirmation by the $\mathrm{CC}$ of unconstitutionality of a given act while postponing the date for the end of its binding force, does not provide to the court any useful tool for resolution of a particular case. See further on this issue: M Florczak-Wątor, 'Skutki prawne odroczenia przez Trybunał Konstytucyjny utraty mocy obowiązującej aktu normatywnego' (2003) 2 Przegląd Sejmowy 45-62; M Florczak-Wątor, 'Względny czy bezwzględny obowiązek stosowania niekonstytucyjnej normy prawnej w okresie odroczenia?' in M Bernatt, J Królikowski, M Ziółkowski (eds) Skutki wyroków Trybunału Konstytucyjnego w sferze stosowania prawa (Warszawa 2013) 113-138.

${ }^{54}$ SC judgment of 29th April 2000, case III RN 96/98. It is also worth noting that subsequent statutes concerning the level of rents for living quarters, issued in 2001 and 2004, did not entirely respect the criteria of constitutionality laid down in the judgment $\mathrm{P}$ 11/98, and were also challenged before the CC (cf. the CC judgment of 2nd October 2002, case K 48/01 and the judgment of 19th April 2005, case K 4/05).
} 


\section{The inheritance of farms (the judgment of 31 January 2001, P 4/99)}

Another illustration of "legal survivals" in the post-communist legal system of the Republic of Poland was the regulation regarding the inheritance of farms.

Special provisions governing the inheritance of farms in Poland, which significantly departed from the general principles of inheritance law, entered into force in 1963. ${ }^{55}$ When the Civil Code entered into force in 1964, these special provisions were included in Title X (Articles 1058 et seq.) of Book Four of the Code. ${ }^{56}$ These provisions were amended (partly liberalised) by amendments to the Civil Code in 1971, 1982 and $1990 .{ }^{57}$ Special inheritance law regulations were supposed to limit the fragmentation of private farms and to limit the obligation of persons having inherited farms to compensate other heirs, not employed in agriculture, who did not inherit the farm. ${ }^{58}$

Until the 1982 amendments it was also possible to discern, in the background of these regulations, a political desire to limit the participation of private ownership in Polish agriculture. ${ }^{59}$ The provisions governing the entitlement of certain persons to inherit farms (universal succession) were based on the concept of limiting the categories of heirs entitled to inherit farms. Certain criteria were required to be fulfilled before a farm could be inherited by an heir in spe. These criteria were connected either with the potential heir's employment in agriculture, with his agricultural education or, conversely, with certain social objectives - the heir being a minor, still studying, or being permanently unable to work. ${ }^{60}$ The legislator entrusted the Council of Ministers with the task of further defining the terms used in the Civil Code by issuing a governmental/ministerial regulation. ${ }^{61}$. Any heir failing to fulfil the criteria specified in the aforementioned provisions had no right to inherit a farm, or to claim compensation from other heirs who did inherit the farm. Until the entry into force of the 1990 amendment, the rules governing the special selection of heirs entitled to inherit farms applied to both statutory (intestate) succession and to testate succession. Only following the adoption of the 1990 amendment were the eligibility criteria abolished in respect of testate succession.

\footnotetext{
${ }^{55}$ Act of 29th June 1963 on the Restriction of the Division of Farms ( hereinafter 1963 Act) Dz. U. No 28, item 168.

${ }^{56}$ In 1969 the SC stated that "there is no doubt that the Polish the inheritance of farms belong to the category of standards aimed at the socialist transformation of the agricultural system, and thus strengthen the socio-economic system, the appropriate goals and objectives of the People's State"(SC judgment of 28 May 1969, case III CZP23/69, OSN 1970, no. 1, item 3).

${ }^{57}$ Civil Code of 23 April 1964 (Dz. U. No 16, item 93; hereinafter Civil Code) with the Provisions introducing the Civil Code (The Act of 23 April 1964 r Dz. U. No 16, item 94), The Act amending the Civil Code of 26 October 1971 (Dz. U. No 27, item 252), The Act of 26 March 1982 r. Amending the Civil Code and Anulling the Act on the Ownership of Farms (Dz. U. No 11, item 81); The Act of 28 July 1990 r. Amending the Civil Code (Dz. U. No 55, item 321).

${ }^{58}$ See futher: S Kalus, M Habdas, Family Law in Poland (Wolters Kluwer 2011) 247.

59 ibid.

${ }^{60}$ Article 5 of the 1963 Act; (Art.icles $1060 \S 2,1062 \S 2,1061$ of the Civil Code).

${ }^{61}$ The Regulation of Council of Ministers of 12December 1990, which was issued pursuant to Article 1064 of the Civil Code.
} 
Until the entry into force of the 1982 amendments, farms were inherited $e x$ lege by the State Treasury where the living heirs of the deceased's family did not fulfil any of the eligibility criteria for inheriting a farm, or where they were all permanently unable to work (Article 1063 of the Civil Code). The 1982 amendment provided for the inheritance of farms in such cases to be governed by the general rules of inheritance (i.e. without the statutory selection of heirs).

After 1989, when constitutional guarantees of private ownership and inheritance were strengthened, an increasing number of people argued that it was unconstitutional to provide for the statutory limitation of heirs entitled to inherit a farm by requiring the fulfilment of specified criteria at the time that the deceased's estate was opened. Other allegations of unconstitutionality stressed that many of the terms used for governing a person's right to inherit a farm (such as "qualifications to manage a farm", "learning of a profession or attending school" or "permanent inability to work") were not directly defined by statute but in the Council of Ministers' Regulation.

In 2001 the application of the Ombudsman and preliminary questions of various courts provided the $\mathrm{CC}$ with the opportunity to review the statute law regarding the inheritance law regarding farms. The initiators of the proceedings before the $\mathrm{CC}$ challenged a number of provisions of the Civil Code which had been amended on a number of occasions. The initiators' claims concerned versions of these provisions which were binding at different periods of time, applying a different constitutional basis of review to each particular version. ${ }^{62}$ In the judgment of $31^{\text {st }}$ January 2001, case $\mathrm{P} 4 / 99$ the CC stated that statutory provisions which have given rise to a legal situation envisaged by their contents may be reviewed from the perspective of their conformity to the binding Constitution of 1997 despite the fact that this was not in force at the time such a legal situation was created, provided that they may form the basis of decisions taken by organs entitled to apply them and, in particular, may constitute the legal grounds for decisions taken by the courts.

The $\mathrm{CC}$ judgment declared the challenged provisions of the Civil Code unconstitutional. Yet, the CC stressed that arguments for the unconstitutionality, as regards the version of those provisions in force on the date that this ruling was pronounced, apply even more so to the rules governing the inheritance of farms, which entered into force with the amendments of 1971, which continued to apply until the Civil Code was amended again in 1982. According to the CC, the crucial factor there was that the limitation of the categories of statutory heirs entitled to inherit a farm rendered it more likely that a farm would be inherited ex lege by the

\footnotetext{
${ }^{62}$ In effect, the provisions of the 1997 Constitution forming the basis of review in the present case were: Article 21(1) (principle of protection of ownership and the right of succession); Article 64(1) (right to ownership and succession); Article 64(2) (the right to equality in respect of the protection of ownership and succession); Article 64(3) (prohibiting the limitation of the right of ownership by sub-statutory acts and prohibiting the violation of the essence of this right); and Article 31(3) (principle of proportionality). Furthermore, Article 1 of Protocol No. 1 to the (European) Convention for the Protection of Human Rights and Fundamental Freedoms was relied upon.
} 
State Treasury (Article 1063 of the Civil Code, in the version which was binding at this time).

The CC stressed that, when ruling on the analysed case, it had also to take account of the fact that application of the new legal position resulting from the judgment to estates opened prior to the promulgation of the judgment would inevitably lead to a collision with constitutional values, in particular those protecting legal security and trust in the law. Accordingly, the $\mathrm{CC}$ considered it justified to minimise the impact of the judgment in the present case on pre-existing legal relationships, assuming the opening of the deceased's estate as the demarcation criterion. However, it concluded that the aforementioned exclusion of retroactivity in respect of the unconstitutional provisions did not apply to Article 1063 of the Civil Code, as originally adopted and subsequently amended in 1971 (which remained in force until 6th April 1982), which specified the circumstances in which a farm (or land contribution) belonging to a natural person would pass to the State Treasury, even though the Treasury was not eligible ex lege to inherit the entire estate. The $\mathrm{CC}$ decided that the purpose of this provision was to allow the State to take over agricultural land, which amounted to a kind of expropriation and violated the essence of the right of succession.

The judgment amounted to the equivalent of a reform of agricultural inheritance law, annulling the system for selecting heirs entitled ex lege to inherit farms. ${ }^{63}$

In view of this, it serves as a good example of the temporality of justice with regard to the constitutional review of "legal survivals". Once again, the $\mathrm{CC}$ was confronted with two different constitutional principles: the right to ownership and the principle of non-retroactivity. As a result, the $\mathrm{CC}$ significantly limited the narrative of discontinuity with the relativisation of the ruling's temporal effects. The $\mathrm{CC}$ had to acknowledge the temporality of justice and to divide the effects of the constitutional review according to the date on which a given provision applied. In relation to estates opened prior to the entry into force of this ruling, the $\mathrm{CC}$ decided to treat the challenged provisions as compatible with the Constitution in order to ensure the continued protection of rights acquired on the basis of such provisions. This was not the case in respect of the challenged provisions applicable to future circumstances.

\section{THE NARRATIVE OF DISCONTINUITY VERSUS THE "VERY IMPERFECT WORLD” OF TRANSITIONAL JUSTICE}

Another aspect of the conceptual collisions between the narrative of discontinuity and the normative and political wreckage of the past regime is the CC's jurisprudence regarding issues of "transitional justice", a conception associated with periods of political change. ${ }^{64}$ One of the features characteristic of "transitional justice" is the assumption that transitions are

\footnotetext{
63 The judgment did not annul, however, the special provisions of the Civil Code concerning legacies, the division of the estate and the calculation of legitimate relation to the inheritance of farms; these provisions are supposed to limit the subdivision of farms and the heirs' obligation to provide compensation.

${ }^{64}$ See further: Ruti Teitel, Transitional Justice (Oxford University Press, New York 2000).
} 
radically discontinuous with both the past and the future. They are discontinuous with the past because the transition is a radical break. They are also discontinuous with the future because, at the end of the transition, one has in place the institutions that mark its end and thus ensues in a new era. ${ }^{65}$ Yet, in periods of transitions, as Ruti Teitel - an internationally recognised authority on international human rights and transitional justice has observed, "the rule of law constitutes as well as is constituted." 66 That means that the narration of discontinuity - as regards the transitional justice - never has an absolute character and that the rule of law during transitions differs from the rule of law during periods of repression and democratic governance just as its role in each of these periods is distinct from the other. ${ }^{67}$

Transitional justice evokes many aspirations: the rule of law, legitimacy, liberalization, nation-building, reconciliation, and conflict resolution. ${ }^{68}$ The primary objective of a transitional justice policy is to end a culture of impunity and establish the rule of law in the context of democratic governance. ${ }^{69}$ The democratization goal, however, may be in tension with other aspirations identified here, such as the new focus on conflict resolution and reconciliation. ${ }^{70}$ Therefore, as A. Czarnota emphasizes in relation to a book of Justice Solyom, "in the specific period of transformation, when the 'rules of the game' are in the process of being created, it is better to place the task in the hands of impartial judges than to leave it to politicians." 71

Within that whole, the concept of transitional justice focuses on legal practices and problems faced by states and societies under transformation, particularly stemming from the fact that law is typically required to serve two ambitions, often in significant tension with each other: to function both as a stable framework of transformation and as a (frequently changing) means of achieving it. In principle, tensions are often thought to flow from the different demands of seeking to instantiate the rule of law in the present, to repair its absence in the past, and to establish conditions for it in the future. Each of these aims may pull in quite different directions from those to which the others tend. ${ }^{72}$

However, even if the transformation is characterised as, alluding to John Rawls, Pablo de Greiff - a Colombian human rights activist specialized in the field of transitional justice - has distinguished transitions as "very

\footnotetext{
${ }^{65}$ D Dyzenhaus, 'Judicial Independence, Transitional Justice and the Rule of Law' (2003) 10 Otago Law Review 348.

${ }^{66}$ Ruti Teitel, 'Transitional Jurisprudence. The Role of Law in Political Transformation, 2009 (1996-1997) 106 The Yale Law Journal 80.

67 A Czarnota, F DuBois, 'The Transitional Rule of Law' (1999) 24.1 Alternative Law Journal 11.

68 Ruti Teilel, 'The Law and Politics of Contemporary Transitional Justice' (2005) 38 Cornell International Law Journal 838.

${ }^{69}$ D Dyzenhaus, 'Judicial Independence, Transitional Justice and the Rule of Law' (2003)

10 Otago Law Review 348.

${ }^{70}$ Teilel (n 68) 838.

${ }^{71}$ Czarnota (n 13) 151.

${ }^{72}$ Czarnota (n 3) 13.
} 
imperfect worlds". ${ }^{73}$ De Greiff points out that efforts to seek justice in times of transition face many practical challenges, and these lead transitions to pursue "hybrid programs of justice" composed of limited numbers of prosecutions focused on top leaders, official or de facto amnesties, truth commissions, lustration and reparation. ${ }^{74}$ These hybrid programmes are born out of necessity, as transitions must settle for the best justice possible given the imperfect circumstances. ${ }^{75}$ Therefore, the narrative of discontinuity in constitutional issues regarding transitional justice encounters many obstacles. Similarly to the jurisprudence concerning "legal survivals", the constitutional issues regarding transitional justice force constitutional courts to balance the narrative of discontinuity (and the idea of retributive justice) with the principle of non-retroactivity (the temporality of justice). ${ }^{76}$ The tug-of-war between the narrative of discontinuity and continuity in the sphere of the jurisprudence of the transitional justice of the $\mathrm{CC}$ will be analysed upon the basis of lustration jurisprudence and on decrees from the period of martial law.

\section{The jurisprudence of the $\mathrm{CC}$ regarding the lustration law}

As mentioned above, transitional justice is often perceived as an exercise in "non-ideal theory". ${ }^{77}$ One of its key aspects, i.e. lustration ${ }^{78}$ proves, in the context of Polish 'refolution', that this thesis is true.

Lustration is usually understood as the screening of persons seeking (or occupying) certain public positions for evidence of involvement with the Communist regime (mainly secret security apparatus) ${ }^{79}$ and can serve as a form of revenge or may be based on confession and aim to promote social reconciliation. No matter what philosophy serves as the foundation for the lustration law, the legislator always has to decide on this crucial issue:

"Whether democratic standards could be applied as adequate instruments in evaluating the reality of the public space subordinated under communism to a completely different philosophy of public life from the one which is typical for a normal democratic country." 80

\footnotetext{
${ }^{73}$ D Gray, 'An Excuse-centered Approach to Transitional Justice' (2006) 74 Fordham Law Review 1061.

74 ibid 1052.

75 ibid.

76 See also W Sadurski, who - referring to the post-communist constitutional courts' judicial decisions regarding lustration - highlighted the question of the degree to which the principle of legality should control the considerations of substantive justice (in) Rights before the Courts. A Study of Constitutional Courts in Post-communist States of Central and Eastern Europe (Springer 2005) 253.

${ }^{77}$ Further on this issue see also: A Czarnota, 'Lustration, Decommunisation and the Rule of Law' (2009) 1.2 Hague Journal on the Rule of Law 307-336; W Sadurski, 'Decommunisation", "Lustration", and Constitutional Continuity: Dilemmas of Transitional Justice in Central Europe', http://cadmus.eui.eu/handle/1814/1869, Central and Eastern Europe After Transition: Towards a New Socio-legal Semantics, Wojciech Sadurski, Alberto Febbrajo (eds).

${ }^{78}$ The term is taken from the Roman lustrum: purification rituals.

${ }^{79}$ Sadurski (n 77) 4.

${ }^{80}$ M Safjan, 'Transitional Justice: The Polish Example, The Case of Lustration' (2007) 1 European Journal of Legal Studies 7.
} 
The legal dimension of this issue is strongly related to the extremely complex problem of retroactivity. Marek Safjan - former president of the $\mathrm{CC}$ and the current judge of the ECJ - observes that:

"It has to be recalled that the communist state authorized by its legal system the use of oppressive and even criminal means. However, it is not evident, whether (and eventually to what extent) we can apply our democratic legal standards to assess the totalitarian past. To answer the question we should make the difficult choice between two different values. The first of them expresses the consequent respect for the maxim lex retro non agit inscribed into rational legal thinking in the European tradition. The second is based on the general idea of justice requiring consequent elimination and penalization of the "evident evil" committed by people even by these who committed crimes authorized by the law. These questions directly reflect the famous Gustav Radbruch dilemmas on the legality of the laws formally adopted by state bodies but at the same time violating the minimal necessary axiological standards of the law." 81

In my opinion, both values are oriented in the narrative of discontinuity. The principle of non-retroactivity drives towards the weak and narrow lustration models, based on confession and conciliation, without repressive sanctions against those who collaborated with the past regime. The general idea of justice is often associated with the process of so-called de-communisation. ${ }^{82}$ In this context it is coloured even more by normative discontinuity.

The Polish legislative practice regarding lustration law has drawn upon both of the aforementioned contradictory values (respect for the principle of non-retroactivity and the general idea of justice requiring the consequent elimination and penalisation of the evident evil of the past regime). ${ }^{83}$ The CC's jurisprudence regarding the Polish lustration law clearly shows the intention to give primacy to the principle of nonretroactivity over the pursuit of retributive justice and decommunisation. The narrative of discontinuity has won on the normative level (in terms of value-normative discontinuity), yet lost its sharpness on the political level. ${ }^{84}$

The act adopted by the Polish Parliament in 1997 adopted a relatively narrow model of lustration involving the most important state

\footnotetext{
81 ibid 7-8.

${ }^{82}$ Decommunisation, in contrast to lustration is supposed to consist of the removal of exmembers of Communist-party (above a certain rank) from prominent positions in a new democratic system (Sadurski (n 77) 6).

${ }^{83}$ Sadurski (n 77) 7.

${ }^{84}$ Although this goes far beyond the scope of this article, it is worthwhile to try to answer the question about such a state of things, looking at the problem from the position of a sociological - after all, TK is the "product" -Polish legal community. See further on the issue of the sociological background of the CC: H Dębska and T Warczok (n 17); H. Dębska, 'Legal Doxa as a Form of Neutralization of Values in the Law. The Case of Polish Constitutional Tribunal' in K Pałecki (ed) Neutralization of Values in Law (Warszawa 2013); H Dębska, Władza. Symbol. Prawo (Warszawa 2015).
} 
officials (deputies, ministers, judges, ambassadors, etc.). ${ }^{85}$ The law guaranteed judicial review of each accusation (based on the so-called 'lustration lie') introduced by a specialised public prosecutor (the 'Advocate of Public Interest', in Polish: Rzecznik Interesu Publicznego, henceforth referred as: API). The law also gave limited access to the files, in practice allowed only to victims, and later -after some amendments in 2001- also to journalists, researchers and finally even to former secret service collaborators (though they were only allowed access to their own personal data). The judicial procedures were lengthy and in many cases the court found against the accusations made on the basis of the documents registered by the communist secret service. ${ }^{86}$

The Lustration Act 1997 created an obligation to undergo "lustration" on persons who, in the democratic Polish Republic, held, or aspired to hold, certain important public offices (e.g. the President of the Republic of Poland, Members of Parliament and the government, judges, prosecutors and advocates). Such persons, if born before 11 May 1972, were obliged to declare, in a formal "lustration declaration", whether they were formerly an officer, employee or collaborator of the security agencies of the communist state. Admission of any such association with the communist security agencies was publicly announced, but did not automatically preclude such a person from holding the aforementioned public offices. Where, however, a person having been involved in co-operation with the communist security agencies had concealed this fact in his/her "lustration declaration", this amounts to a "lustration lie" which resulted in the automatic loss of any public office currently held by that person and a prohibition against holding such an office for a subsequent period of 10 years. All "lustration declarations" were verified by the API, who was nominated by the First President of the SC. If the API, in the course of verifying a "lustration declaration", formed a reasonable suspicion as to the truthfulness of such a declaration, he could initiate "lustration proceedings", acting as the public prosecutor. The judicial pronouncement of a "lustration lie" was the responsibility of the "lustration court" - a special court division within the Warsaw Court of Appeal. The subject of "lustration" has been the subject of litigation, as well as much legal and political discourse, for many and numerous provisions of the Lustration Act 1997, as amended, have been the subject of various $\mathrm{CC}$ judgments ${ }^{87}$

In one of them - the judgment of $28^{\text {th }}$ May 2003, case K 44/02 - the $\mathrm{CC}$, sitting as a full court, ruled on the constitutionality of the amendment of the Lustration Act 1997 that excluded from the definition of "co-operation" with communist security agencies any co-operation relating to matters of intelligence, counter-intelligence or border protection. ${ }^{88}$ The $\mathrm{CC}$ held that

\footnotetext{
85 The first lustration act was passed by the Polish Parliament as early as in 1992, but it was declared unconstitutional by the CC. See further on that issue Sadurski (n 77) 27 ((the Decision of $19^{\text {th }}$ June 1992 , U 6/92).

${ }^{86}$ Safjan (n 80) 10; Sadurski (n 77) 28-29.

${ }^{87}$ W 5/93, K 24/98, K 39/97, P 3/00, SK 10/99, SK 28/01, K 7/01 and K 11/02.

${ }^{88}$ It should be noted that the amending Act excluded such matters only in relation to informal "co-operation" and did not preclude the lustration process from continuing to apply to those who performed such tasks in the course of employment or service.
} 
the amending Act was unconstitutional, and this resulted in a reversion to the law prior to the amending Act.

One of the most important theses formulated by the $\mathrm{CC}$ in the analysed judgment regards the discontinuity of the political system in Poland and the tendency to cast off the communist past. The CC stated that:

"The principle of the continuity of the Polish State does not mean the continuity of the axiological foundations of statehood and the legal system in force before and after the political breakthrough of 1989 . The constitutional expression of the lack of such continuity results from the Act of 29 December 1989, which amended the 1952 Constitution of the Polish People's Republic [Polska Rzeczpospolita Ludowa, i.e. the official name of Poland under the communist regime - A.K.], removing all references of the law in force to values on which the Polish constitutional system during the communist regime of 1944-1989 was based."

This passus of the judgment may by be treated as a declaration in terms of J.L. Austin's illocutionary acts theory. That means that the speech act of the $\mathrm{CC}$ has the illocutionary force in terms of a speech acts theory, to give the constitutional amendment of $2^{\text {th }}$ December 1989 power to "swear reality". Taking into account the position presented above, the CC held that:

"The lustration procedure (...) is a mechanism for testing the truthfulness of "lustration declarations" about any co-operation between the security agencies of the communist state and persons currently holding or seeking certain public offices involving special responsibilities. The 1997 Act does not deem reprehensible, nor impose sanctions for, the mere fact of such co-operation with State security agents during the years 1944-1990, but rather the concealment of any such co-operations or relationships in the lustration declaration. The Act aims to ensure that the most important public offices are held by persons who are truthful and therefore trustworthy."

When reading this excerpt of the judgment, it is worthwhile to remember that the CC is "one of the subjects involved in the legal field, as well as the entire field of power. Through discursive procedures (...), which it uses in the text of its judgments, it incorporates particular pattern and values which are compatible with the rules established in the legal field." 89 In the context of lustration teleology the CC gives precedent to non-retroactivity over the idea of retributive justice, as it emphasizes non-penal character of the lustration procedure.

Such a hierarchy of values became publicly contested in 2006, when the right-wing "Law and Justice" party's government (which came to the election as the only 'non-communist party') proclaimed the urgent need for large-scale lustration. ${ }^{90}$ Therefore, the main element of the procedure adopted in the 2006 Lustration Act was a broad lustration which involved not only the high state officials, but also the middle level of administrative

\footnotetext{
${ }^{89}$ Dębska (84) 350

90 The act was the Law and Justice government's pet project in its mission to clear the public sector of old communists.
} 
public servants and even private sector employees (academics, journalists, lawyers, as well as legal and tax counsellors, members of the boards of state companies). ${ }^{91}$

Another characteristic of the new law was the large public access (guaranteed to everyone) to the secret files, including to data about present and former senior public officials. Access to that information was additionally ensured by the publication made by the State institution - the Institute of National Remembrance (in Polish: Instytut Pamięci Narodowej, hereinafter: the INR) - of official lists with the names of people who were registered with the security services. The people who did not agree to submit a "lustration declaration" and those who lied (or concealed the fact of their cooperation) were threatened with serious administrative penalties, including the loss of the posts they occupied for 10 years. This could result in the termination of the professional activity of journalists (who could lose the right to publish) or of scientists (who could lose the right to teach and carry out research for a lengthy period of time). ${ }^{92}$

The key articles of the 2006 Lustration Act were judged unconstitutional by the CC on May 11, 2007 (Case K 2/07) - right before the contested lustration procedure was to take effect, and thus blocking the whole process in question. ${ }^{93}$ In the decision, the $\mathrm{CC}$ pointed out that:

"a state based on the rule of law should not fulfill a craving for revenge instead of fulfilling justice".

This position evidently gives primacy to the rule of law and the nonretroactivity approach over the idea of retributive justice, and therefore relativises the discontinuity on the political level. On the other hand, it also shows the strength of post-communist democracy based on the value and normative discontinuity.

The jurisprudence of the $\mathrm{CC}$ regarding lustration law in Poland seems to be based on the premise of a limited trust to the very idea of lustration process. To some extent this standpoint may result from the fact that the strong version of lustration was applied in Poland more than 15 years after the 1989. This circumstance deepened doubts concerning the reliability of the documents which, inevitably, were to become the main proof of past collaboration, namely the files of the former secret police apparatus. ${ }^{94}$ Another theme in the debates around lustration which the CC must have taken into account concerned its consequences for the newly democratized society. As Wojciech Sadurski - distinguished Polish legal scholar specialized in legal and political philosophy - put this dilemma into words: "is it wise to reopen old wounds and create divisions in the society

\footnotetext{
${ }^{91}$ Lustration by the IPN was to be obligatory for 53 categories of people born before August 1, 1972, who held positions of significant public responsibility, including lawyers, public notaries, attorneys, journalists and academics.

92 The act of 18 October 2006 on disclosure of information about documents of State security bodies in the years 1944-1990 and the content of these documents (Polish: Ustawa z dnia 18 października 2006 r. o ujawnianiu informacji o dokumentach organów bezpieczeństwa państwa z lat 1944-1990 oraz treści tych dokumentów; Dz. U. No 218, item 1952); see also: M. Safjan, ...p. 11.

${ }^{93}$ However, the decision was reached despite a record number of dissenting opinions.

${ }^{94}$ Sadurski (n 77) 5.
} 
which needs strong mobilization and coherence to handle to handle the challenges it is facing." 95

A. Czarnota has observed that it is salient to decide "(...) whether, in the hybrid post-communism, emphasis should lie on the prefix or the suffix. It makes a difference. If the region is seen as primarily post-communist, we can regard the communist past as some sort of dream or nightmare, which dissipates on waking. Many newly minted experts and advisors from the West tended to favour this interpretation, often unreflectively. Communism was the past and perhaps had left rubbish that needed to be removed, but postcommunism is the present and future. The more you believe this, the less you need to understand communism. But if you take it to mean that the region is postcommunist, there is a clear suggestion that the communist past, or its legacies, retain present effects." decided to put the emphasis on the prefix. At the level of judicial reasoning the $\mathrm{CC}$ justified this decision by recognizing the primacy of the prohibition of retroactivity in relation to the idea of retributive justice.

\section{Decrees on martial law}

Another aspect of the jurisprudential tension between the nonretroactivity principle and the idea of retributive justice is the CC judgment of 16 March 2011 (K 35/08) concerning the constitutionality of the decrees imposing martial law. ${ }^{97}$ Contrary to the lustration jurisprudence, the analysed judgment might be regarded as a nod towards the general idea of justice. Such an assessment of this judgment stems primarily from the fact that by far the activist position of the $\mathrm{CC}$ which decided to review a decree on the introduction of martial law, formally repealed in 1983, in terms of its compliance with the binding Constitution of 1997. In this controversial judgment the CC decided that the introduction of martial law in Poland in December 1981 was contradictory to the Constitution.

The motion was filed by the Ombudsman and was elicited by the fact that the SC, in the resolution of 20 December $2007^{98}$, decided that the

\footnotetext{
95 ibid 6.

${ }^{96}$ M. Krygier, A. Czarnota, 'After Communism: The Next Phase' (2006) 2 Annual Review of Law and Social Science 299-340, 300.

${ }^{97}$ Martial law in Poland refers to the period of time from 13 December 1981 to 22 July 1983, when the authoritarian communist government (the Military Council of National Salvation, in Polish Wojskowa Rada Ocalenia Narodowego, hereinafter: MCNS) of the People's Republic of Poland drastically restricted normal life by introducing martial law in an attempt to crush political opposition. ${ }^{97}$ The instigators of the martial law (led by General of the Army Wojciech Jaruzelski), argued that the army crackdown rescued Poland from a possibly disastrous military intervention of the Soviet Union, East Germany, and other Warsaw Pact countries (similar to the earlier "fraternal aid" interventions in Hungary 1956, and Czechoslovakia 1968). However, there are no sources confirming such a version of events. ${ }^{97}$ Although - as mentioned - martial law was lifted in 1983, many of the political prisoners were not released until the general amnesty in 1986. Further on this issue see: Andrzej Paczkowski, Malcolm Byrne (eds), From Solidarity to Martial Law: The Polish Crisis of 1980-198: A Documentary History (Central European University Press, Budapest 2007); George Sanford, Military Rule in Poland: The Rebuilding of Communist Power, 1981-1983; Leopold Labedz, Poland Under Jaruzelski: A Comprehensive Sourcebook on Poland During and After Martial Law.

${ }^{98}$ Case I KZP 37/07.
} 
SC judges of the 80s had to apply the Decree of martial law from 1981. Among other things, the argumentation was based on the fact that there was no constitutional review at that time and the lack of a constitutional ban on retroactivity. According to the SC the allegations against the judges could also not be invoked because the International Covenant on Civil and Political Rights (hereinafter: the ICCPR) ${ }^{99}$, ratified by the Polish People's Republic in 1977, that prohibited retroactivity of criminal law was not directly applicable in the Polish legal system of those times. ${ }^{100}$

It is now known that the Decree of 12 December was printed in the Official Gazette of 17 December 1981 - and - even according to the Constitution of 1952 - it could be binding only from that date. However, in the Official Gazette there was the date of December 14, together with the retroactive binding force starting from 12 December 1981. Such pre-dating by the communist authorities came to light only in 1991.

The resolution of the SC meant, in practice, that the INR was not able to charge judges for the retroactive application of the Decree of 12 December. Setting the charges required the repeal of the immunity of judges. INR in Katowice wanted to put allegations of abuse of power 24 prosecutors and judges (including two retired SC judges), who accused, condemned, and extended arrests against activists of Solidarity between 12 and 161981 December, when the decree - as mentioned above - was not yet in force.

The primary effect of the CC judgment was to enable IRN submitting again requests to waive the immunities of judges adjudicating on the basis of the decree of martial law.

The introductory decrees imposing martial law were issued on 12 of December 1981, when the Sejm (Polish Parliament) was officially in session. In this context it is worth noting that one of the standards of the review indicated by the Ombudsman was Article 31(1) of the Constitution of 1952. Pursuant to that provision the Council of State (collegial head of State) issued the decrees only between sessions of the Sejm. Furthermore, the Constitution of 1952 did not make any provisions regarding the issuing by the Council of State of legal acts during sessions of the Sejm.

As the decrees of 12 December 1981 were issued during a session of the Sejm, the CC decided that the Council of State had violated the provisions of the Constitution by acting in this way. The CC pointed out that under the rule of law the state authorities were required to act solely on the basis of the law. Violating this rule made the decrees of 12 December 1981 illegal. In the opinion of the CC, the activity of the Council of State violated not only the legislative proceedings but also the general rules concerning the activity of public administration. The $\mathrm{CC}$ also noted that there was a direct link between the infringement of requirements concerning the scope of

\footnotetext{
${ }^{99}$ See: http://www.ohchr.org/EN/ProfessionalInterest/Pages/CCPR.aspx

100 The Constitution of 1952 did not specify the place of international law in domestic law, leaving this doctrine and case law. Over the forty years of the Constitution of 1952, they surged between extremely contradictory concepts. Further on this issue, with illustrations from the CC and the SC judicial decisions, see M Masternak-Kubiak, Umowa międzynarodowa $w$ prawie konstytucyjnym (Warszawa 1997), L Garlicki, M MasternakKubiak, K Wójtowicz, 'Poland' in David Sloss (ed), The Role of Domestic Courts in Treaty Enforcement: A Comparative Study 371.
} 
powers of the Military Council of National Salvation, when enacting the decrees and the infringement of human rights. The Constitution of 1952 guaranteed, and the Constitution of 1997 guarantees, rights which ensure that the individual and other private entities are protected against interference from the organs of public authority undertaken ultra vires.

The CC held that issuing a normative act which was ultra vires and introduced restrictions on constitutional rights, resulted in an infringement of those rights. Indeed, such an act leads to the issuing of decisions based upon it which further interfere with constitutional rights, thus triggering a series of actions undertaken without a proper legal basis. From the point of view of the individual, legal interference undertaken ultra vires is no less burdensome than interference infringing on the substantive requirements set out in the Constitution. The protective role of fundamental rights is of particular significance in the case of the right guaranteed by the prohibition of the retroactivity of a criminal law.

The CC emphasized that after 1989, with the rejection of the primacy of the Communist Party and the introduction of the principle of a democratic state ruled by law, changes were made to the constitutional regulation of human and civil rights and freedoms, as well as to the approach to safeguarding them. The constitution-maker assigned key significance to the formal means of protecting rights and freedoms. The rights guaranteed in Constitution of 1952 and the binding Constitution of 1997, in their essence, are the same rights, but they are more strictly protected and are subject to more effective formal safeguards. However, the Constitution of 1997 guarantees rights which were not expressis verbis guaranteed at the constitutional level prior to 17 October 1997. A majority of those rights were, however, recognized in the Polish legal system. They arose from the ICCPR, which - according to the CC - was binding for the Polish legislator.

The salient part of this argumentation is the thesis about the continuity of the fundamental rights protection before and after 1997. It enabled the $\mathrm{CC}$ to review the compliance of the martial law decrees with the currently binding standards of constitutional rights protection. Such a declaration, however, is a salient gap in the general premise of constitutional discontinuity after 1989.

The CC found that the Decree on Martial Law ${ }^{101}$ infringed standards of protection arose from the ICCPR. Above all, the repressive character of

\footnotetext{
${ }^{101}$ The CC stated that the issuing of a ruling, which concerned the constitutionality of the Decree on Martial Law and the Decree on Special Proceedings, was necessary to protect constitutional rights and freedoms. Those two Decrees exhausted the issue of the protection of constitutional rights and freedoms and the substantive considerations of the $\mathrm{CC}$ concerned the Decree on Martial Law and the Decree on Special Proceedings. On the contrary, the CC concluded that issuing a ruling on the Decree on the Jurisdiction of Military Courts was useless, and discontinued the proceedings within that scope. The Ombudsman presented no arguments justifying the necessity for the issuing of a ruling on the provisions contained in the Act on special legal regulation during the period of martial law. The $\mathrm{CC}$ therefore concluded that the issuing of a ruling with regard to the Act on special legal regulation during the period of martial law was not indispensable for ensuring the protection of constitutional rights and freedoms, and discontinued the proceedings within that scope.
} 
the Decree manifested itself in the fact that it penalised acts which had not been regarded as criminal before 13 December 1981. ${ }^{102}$ The CC emphasised that that the challenged decrees were promulgated on 18 December 1981 and only on that day, in accordance with their final provisions, they entered into force, despite the fact that the edition of the Official Gazette they were published in was dated 14 December.

The CC judgment on the decrees on martial law shows how difficult it is to rightly asses the constitutional jurisprudence on legal discontinuity. On one hand the judgment is an evident gap in the main stream judicial approach regarding the transition that is the constitutional discontinuity. Such a gap results from the argumentation based on the premise that the protection of fundamental rights before and after 1997 is a continuum, which allowed the $\mathrm{CC}$ to review the compliance of the decrees on martial law with the principle of the non-retroactivity of criminal law. On the other hand the thesis on the continuity of fundamental rights protection enabled the reinforcing of instruments of retributive justice as regards the judiciary during the Communist regime. Such a judicial decision must be therefore perceived as an example of drawing a thick line between the past and present political systems.

From the individual perspective, the $\mathrm{CC}$ ruling made it possible to re-open criminal proceedings where the provisions of repressive law, contained in the decrees, were applied. In this regard, the CC established that adjudicating on the decrees concerning martial law was necessary for the protection of constitutional freedoms and rights. ${ }^{103}$ Such argumentation also indicates the willingness to rectify the wrongs of the past. Yet it proves, at the same time, how difficult it is to harmonize the Symbolic register of discontinuity with the Realm of inevitable and irreversible continuity in the legal and judicial dimension.

\section{CONCLUSIONS}

Regardless of the stage of the political transition, both the constitution-creators and the constitutional judiciary tend to distance themselves from the past. The Polish CC's jurisprudence is not an exception to this rule. However, deeper analysis of the Polish constitutional jurisprudence reveals salient elements of continuity that stain the white sheet of the brand new constitutional narration. Such a situation often results from the lack of a new written constitution, since the remaining old constitutional environment significantly affects the constitutional court's jurisdiction, both in its merits and effects.

\footnotetext{
102 The decrees also introduced harsher penalties for acts that were prohibited under the law at that time, and categorised numerous previous misdemeanors as offences. Repressive provisions were aimed at suppressing the freedoms of speech, association, publication and assembly, as well as other freedoms and rights.

${ }^{103}$ Yet, at the same time, the CC acknowledged that many of the rights and freedoms could not be restored, nor the infringement thereof compensated. The CC held also that issuing a judgment was significant for enhancing the rule of law and - regardless of its limited direct impact - for preserving the principle of the protection of citizens' trust in the state and its institutions.
} 
As A. Czarnota notes "symbolically a new law-governed state, as stated in amendments to the constitutions, was born as a legitimate child of a communist regime that typically had been installed illegally and had operated with no respect for law. This combination of continuity with discontinuity has created tensions between the demands of legality and those of preserving the revolutionary ethos, with its commitment to material justice, where they existed." 104 In Poland the basic aspect of piecemeal constitutional continuity followed from the fact that the principle of the democratic state ruled by law was introduced into the constitutional system as an amendment of Constitution of 1952. On the levels of both constitutional and statutory law such continuity was also guaranteed (at least to some extent) by legal provisions regulating the CC's competences and the effects of the CC's judicial decisions (e.g. the Sejm's right to overrule them).

Yet, even after the entry into force of the new Constitution of 1997, the narrative of constitutional discontinuity did not (and could not) prevail in Poland. The new democratic State has had to cope with many salient post-transition constitutional issues that demanded taking into account the temporality of justice and thus - sometimes - giving priority to aspects of legal continuity. Some of them regarded so called "legal survivals" of the old regime, others were linked to the idea of transitional justice. In this regard the $\mathrm{CC}$ jurisprudence serves as a conspicuous example of prioritizing elements of constitutional continuity in various forms of the relativisation of the CC's judgments (making effects of judgments conditional on the period of time when the factual and legal situation of individuals was established or deferring the loss of force of unconstitutional regulation).

As regards transitional justice, the jurisdictional tussle between the leading narrative of constitutional discontinuity and the elements of constitutional continuity in the Polish legal system seem slightly more tangled. Issues regarding transitional justice also force constitutional courts to take into account the temporality of justice, yet outcomes of judgments appear more sophisticated. While the CC's jurisprudence regarding the lustration law is an illustration of a position that gives primacy to the rule of law and non-retroactivity over the idea of retributive justice (thus relativising the discontinuity on the political level ${ }^{105}$ ), the judgment on decrees from the period of martial law is rather a nod towards the general idea of justice at the expense of the principle of non-retroactivity.

Regardless of these salient differences, all the judicial decisions presented in this paper prove that the absolute discontinuity of the constitutional past seems to be an unreachable ideal. In the sphere of judicial practice such a premise must be always confronted - willingly or not - with the "refolutional" character of most transitions. And it is not an easy task for the constitutional court to balance the narrative based on the premise of

\footnotetext{
${ }^{104}$ Czarnota (n 4) 15.

105 On the other hand, it also shows the strength of post-communist democracy based on the new axiology and normative system (which are both elements of constitutional discontinuity).
} 
constitutional discontinuity with the legal and political reality of the still existing remnants of the old regime.

\section{Bibliography}

Ash TG, The Magic Lantern: The Revolution of '89 Witnessed in Warsaw, Budapest, Berlin, and Prague (Vintage Books 1993).

Banaszak B, 'Aktywizm orzeczniczy polskiego Trybunału Konstytucyjnego' in B Banaszak, M Bernadczyk (eds) Aktywizm sędziowski we współczesnym państwie demokratycznym (Warszawa 2012).

Brzezinski M, 'Constitutional 'Refolution' in the Ex-Communist World: The Rule of Law (1997) 12 American University International Law Review 90

Brzezinski MF, Garlicki L, 'Judicial Review in Post-Communist Poland: The Emergence of a Rechtsstaat?' (1995) 16 Stanford Journal of International Law 13

Cholewiński R, 'The protection of Human Rights in the new Polish constitution' (1998) 22.2 Fordham International Law Journal 283.

Czarnota A, 'Foreword' (2001) 29 East Central Europe (part 1) V.

Czarnota A, 'Guardians of the Constitution or legislative Bodies?' (2001) 28 East Central Europe (part 1) 147-152.

Czarnota A, 'Lustration, Decommunisation and the Rule of Law' (2009) 1.2 Hague Journal on the Rule of Law 307

Czarnota A, 'Transitional Justice, The Post-Communist Post-Police State and the Losers and Winners. An Overview of the Problem' (2009) 1 Silesian Journal of Legal Studies 13.

Czarnota A, DuBois F, 'The Transitional Rule of Law' (1999) 24.1 Alternative Law Journal 11.

Dębska H, 'Legal Doxa as a Form of Neutralization of Values in the Law. The Case of Polish Constitutional Tribunal' in K Pałecki (ed) Neutralization of Values in Law (Wolters Kluwer 2013)

Dębska H, Władza. Symbol. Prawo. Społeczne tworzenie Trybunału Konstytucyjnego (Wydawnictwo Sejmowe 2015).

Dębska H, Warczok T, 'Sacred Law and Profane Politics. The Symbolic Construction of Constitutional Tribunal' (2014) 4(188) Polish Sociological Review 469.

Dyzenhaus D, 'Judicial Independence, Transitional Justice and the Rule of Law' (2003) 10 Otago Law Review 348.

Florczak-Wątor F, 'Względny czy bezwzględny obowiązek stosowania niekonstytucyjnej normy prawnej w okresie odroczenia?' in M Bernatt, J Królikowski, M Ziółkowski (eds) Skutki wyroków Trybunatu Konstytucyjnego w sferze stosowania prawa (Warszawa 2013).

Florczak-Wątor M, 'Skutki prawne odroczenia przez Trybunał Konstytucyjny utraty mocy obowiązującej aktu normatywnego' (2003) 2 Przegląd Sejmowy 45.

Frankowski S, Bodnar A (eds), Introduction to Polish Law (Hague, Kraków 2005).

Frankowski S, Stephan III PB (eds), Legal Reform in Postcommunist Europe. The View from Within (Kluwer 1995). 
Garlicki L, "The Necessity and Functions of the Constitution" paper given at the Symposium on the "European Constitutional Area" held at the Swiss Institute for the Comparative Law, Lusanne, Switzerland, 9-12 April 1995.

Garlicki, L., Masternak-Kubiak, M.,Wójtowicz, K. 'Poland' in David Sloss (ed), The Role of Domestic Courts in Treaty Enforcement: A Comparative Study (Cambridge University Press 2009) 371.

Gray D, 'An Excuse-centered Approach to Transitional Justice' (2006) 74 Fordham Law Review 1061.

Greiff P de, 'International Courts and Transitions to Democracy' (1998) 12.1 Public Affairs Quarterly 74.

Herspring D, "Refolution' in eastern Europe: The Polish, Czech, Slovak and Hungarian militaries' (1994) 3.4 European Security 664.

Kalus S, Habdas M, Family Law in Poland (Wolters Kluwer 2011).

Krygier M, Czarnota A, 'After Communism: The Next Phase' (2006) 2 Annual Review of Law and Social Science 299.

Labedz L, Poland Under Jaruzelski: A Comprehensive Sourcebook on Poland During and After Martial Law (Scribner 1984).

Mańko R, 'Demons of the Past? Legal Survivals of the Socialist Legal Tradition in Contemporary Polish Private Law' in Cosmin Sebastian Cercel, Rafał Mańko, Adam Sulikowski (eds) Law and Critique in Central Europe: Questioning Past, Resisting Present (Countepress 2016).

Mańko R, 'Is the Socialist Legal Tradition “'Dead and Buried?" The Continuity of the Certain Elements of Socialist Legal Culture in Polish Civil Procedure' in Thomas Wilhelmsson, Elina Paunio \& Annika Pohjolainen (eds), Private Law and the Many Cultures of Europe (Kluwer Law International 2007).

Mańko R, 'Survival of the Socialist Legal Tradition? A Polish Perspective' (2013) 4.3 Comparative Law Review 1.

Mańko R, 'Weeds in the Gardens of Justice? The Survival of Hyperpositivism in Polish Legal Culture as a Symptom/Sinthome' (2013) 7.2 Pólemos - Journal of Law, Literature and Culture 207.

Masternak-Kubiak M, Umowa międzynarodowa $w$ prawie konstytucyjnym (Warszawa 1997).

Morawski L, 'Spór o pojęcie państwa prawnego' (1995) 8 Państwo i Prawo.

Paczkowski A, Byrne A (eds), From Solidarity to Martial Law: The Polish Crisis of 1980-198: A Documentary History (Central European University Press, Budapest 2007)

Pałecki K, 'O aksjologicznych zmianach w prawie' in L Leszczyński (ed), Zmiany społeczne a zmiana $w$ prawie. Aksjologia, Konstytucja, Integracja Europejska (Lublin 1999).

Pałecki K, 'Zmiany w aksjologicznych podstawach prawa jako wskaźnik jego tranzycji' in K Pałecki (ed) Dynamika wartości w prawie (Kraków 1997).

Přibáň J, Legal Symbolism: On Law, Time and European Identity (Ashgate 2007). 
Rosenfeld M, 'The Rule of Law and the legitimacy of Constitutional Democracy' 74 Southern California Law Review 1307.

Sadurski W, 'Decommunisation", "Lustration", and Constitutional Continuity: Dilemmas of Transitional Justice in Central Europe' in: Central and Eastern Europe After Transition: Towards a New Socio-legal Semantics, Wojciech Sadurski, Alberto Febbrajo (eds).

Sadurski W, Rights before the Courts. A Study of Constitutional Courts in Post-communist States of Central and Eastern Europe (Springer 2005) 253.

Sadurski W, The Study of Constitutional Courts in Post-communist States of Central and Eastern Europe (Dortrecht, Springer 2005).

Safjan M, 'Transitional Justice: The Polish Example, The Case of Lustration' (2007) 1 European Journal of Legal Studies 2. Available online: http://cadmus.eui.eu/bitstream/handle/1814/7711/EJLS_2007_1_2_10_SAF EN.pdf?sequence (visited 22 February 2018).

Sanford G, Military Rule in Poland: The Rebuilding of Communist Power, 1981-1983 (Palgrave Macmillan 1986).

Sarnecki P, 'Ustrój polityczny Polski po wejściu w życie ustawy konstytucyjnej z 7 kwietnia 1989 r.', (2009) 3(92) Przegląd Sejmowy 17.

Schmitt C, Theory of Constitution-making Power (Duke University Press 2008) 144.

Şen IG, Sovereignty Referendums in International and Constitutional Law (Springer 2015)

Sulikowski A, 'Government of Judges and Neoliberal Ideology: The Polish Case' in Cosmin Sebastian Cercel, Rafał Mańko, Adam Sulikowski (eds) Law and Critique in Central Europe: Questioning Past, Resisting Present (Countepress 2016).

Teilel R, 'The Law and Politics of Contemporary Transitional Justice' (2005) 38 Cornell International Law Journal 838.

Teitel T, 'Transitional Jurisprudence. The Role of Law in Political Transformation, 2009 (1996-1997) 106 The Yale Law Journal 80. 2000).

Teitel T, Transitional Justice (Oxford University Press, New York

Uitz R, Constitutions, Courts and History. Historical Narratives in Constitutional Adjudication (Central European University Press 2005)

Visegrády I, "Transition to Democracy in Central and Eastern Europe: Experiences of a model country - Hungary" 1.2 William and Mary Bill of Rights Journal 245.

Zubik R, 'Polish Constitutionalism and the Constitutional Judiciary in Poland V.6 Hungarian $\quad$ Review 3 (http://www.hungarianreview.com/article/Polish\%20Constitutionalism\%20a nd\%20the\%20Constitutional\%20Judiciary\%20in\%20Poland). 